\title{
PERHITUNGAN BIAYA SISTEM MANAJEMEN KESELAMATAN DAN KESEHATAN KERJA (SMK3) PADA STRUKTUR BANGUNAN ATAS PROYEK HOTEL SWISS-BELINN JUANDA
}

\author{
R. A. Triaswati M. N. ${ }^{1}$, P Candra Valentina Mokshita Utama ${ }^{2}$ dan Akhmad Yusuf Zuhdy ${ }^{3}$ \\ 1,2,3 Jurusan Teknik Infrastruktur Sipil, Fakultas Vokasi, Institut Teknologi Sepuluh Nopember \\ Email: triaswatimn@gmail.com
}

\begin{abstract}
ABSTRAK
Dalam konstruksi pembangunan, Indonesia merupakan negara berkembang yang memiliki tingkat kefatalan kecelakaan kerja yang tinggi menurut International Labour Organization (ILO). Hal ini dikarenakan banyaknya pekerja dalam suatu proyek sehingga membutuhkan manajemen keselamatan dan kesehatan kerja (SMK3) yang baik. Namun, masih banyak perusahaan yang tidak menerapkan SMK3 bahkan termasuk proyek-proyek konstruksi yang berada di kota-kota besar. Hal ini didasari akan keinginan perusahaan dalam memperoleh profit yang tinggi sehingga mengabaikan keselamatan dan kesehatan pekerja. Dengan sistem manajemen K3 yang baik, setidaknya akan mencegah atau mengurangi risiko kecelakaan kerja yang ada. Program sistem manajemen K3 diawali dengan mencari potensi bahaya dari metode pelaksanaan yang digunakan agar dapat mengidentifikasi risiko yang ada, penilaian risiko dengan skala prioritas dan pengendalian bahaya yang harus dilaksanakan dimana pengendalian bahaya tersebut akan dilengkapi dengan program sosialisasi dan pelatihan K3. Dengan demikian, pekerja dapat bekerja dengan baik dan aman sehingga dapat mencapai target waktu dan target kualitas yang diinginkan dan direncanakan. Studi kasus yang diambil adalah struktur bangunan atas pada proyek Hotel Swiss-Belinn Juanda yang memiliki total 8 lantai dengan batasan pekerjaan bangunan atas, yaitu pekerjaan pembesian, bekisting, pengecoran. Dari sistem manajemen K3 yang direncanakan tersebut diperoleh biaya pengendalian risiko sejumlah $\mathrm{Rp} 310.266 .500,00$ yang dapat menjadi acuan dalam menekan angka kecelakaan.
\end{abstract}

Kata kunci: Potensi Bahaya, Identifikasi Risiko, Pengendalian Risiko, Sistem Manajemen K3

\section{PENDAHULUAN}

Indonesia adalah negara berkembang yang memiliki pendapatan per kapita yang rendah dengan jumlah tenaga kerja tertinggi kedua di dunia dan di Asia Tenggara juga menduduki regional tertinggi kedua tingkat kefatalan kecelakaan kerja (Ilo, 1995). Hal ini dikarenakan konstruksi di Indonesia dapat mempekerjakan ratusan tenaga kerja pada suatu proyek. Pekerja harus dilindungi oleh sistem manajemen keselamatan dan kesehatan kerja (SMK3). Banyaknya proyek-proyek konstruksi di kota-kota besar masih belum memiliki SMK3. Dengan perencanaan dan penerapan SMK3 yang baik akan mengurangi risiko kecelakaan kerja.

Peraturan Menteri Pekerjaan Umum No.05/PRT/M/2014(Indonesia, 1980) tentang pedoman SMK3 meliputi kebijakan, perencanaan, pengendalian, pemeriksaan dan evaluasi, serta tinjauan ulang[1][8][10]. Dengan adanya SMK3, maka dapat menghasilkan biaya pelaksanaan K3.

\section{METODOLOGI}

Data-data yang berupa metode pelaksanaan dengan item pekerjaan diidentifikasi risiko dari potensi-potensi bahaya yang ada di proyek berdasarkan Job Safety Analysis (JSA) yang secara rinci dan 
sistematis. Potensi bahaya tersebut dilakukan penilaian dengan skala prioritas berdasarkan matriks kekerapan dan keparahan[1] bahaya lalu direncanakan pengendalian bahayanya. Pengendalian risiko diikuti oleh sasaran khusus yang membutuhkan standar, prinsip, atau spesifikasi yang memenuhi yang dimana menggunakan NSPK dan NSPM. Program-program K3 yang mendukung seperti bahan dan alat yang digunakan, pekerja dan lingkungan yang mendukung layaknya pelatihan dan safety induction serta monitoring dan audit. Setelah program-program ditentukan maka disusun biaya pelaksanaan pengendalian $\mathrm{K} 3$.

Tabel 1. Parameter Kekerapan

\begin{tabular}{|c|l|}
\hline Nilai & \multicolumn{1}{|c|}{ Kekerapan } \\
\hline 1 (satu) & $\begin{array}{l}\text { Jarang terjadi dalam kegiatan } \\
\text { konstruksi }\end{array}$ \\
\hline 2 (dua) & $\begin{array}{l}\text { Kadang-kadang terjadi dalam } \\
\text { kegiatan konstruksi }\end{array}$ \\
\hline 3 (tiga) & $\begin{array}{l}\text { Sering terjadi dalam kegiatan } \\
\text { konstruksi }\end{array}$ \\
\hline
\end{tabular}

Tabel 2. Parameter Keparahan

\begin{tabular}{|c|l|c|}
\hline TINGKAT & \multicolumn{1}{|c|}{$\begin{array}{c}\text { KEPARAHAN/KERUGIAN/ } \\
\text { DAMPAK }\end{array}$} & Nilai \\
\hline RINGAN & $\begin{array}{l}\text { Terpeleset, polusi debu, } \\
\text { terserempet, pengobatan } \\
\text { P3K/klinik, dapat lanjut bekerja }\end{array}$ & 1 \\
\hline SEDANG & $\begin{array}{l}\text { Tersengat aliran listrik, polusi } \\
\text { debu, menghirup gas beracun, } \\
\text { terkilir, kebisingan, pengobatan } \\
\text { diluar proyek, maks.istirahat } \\
\text { selama 2 X 24 jam }\end{array}$ & 2 \\
\hline BERAT & $\begin{array}{l}\text { Tersengat aliran listrik, } \\
\text { menghirup gas beracun, patah } \\
\text { tulang, gegar otak, meninggal, } \\
\text { luka berat, rawat inap, } \\
\text { kehilangan hari kerja 2 } \times 24 \text { jam, } \\
\text { cacat fungsi/organ }\end{array}$ & 3 \\
\hline
\end{tabular}

Tabel 3. Skala Prioritas

\begin{tabular}{|c|c|c|c|c|}
\hline \multicolumn{2}{|c|}{$\begin{array}{c}\text { Tingkat Risiko K3 } \\
\text { Konstruksi }\end{array}$} & \multicolumn{3}{|c|}{ Keparahan } \\
\cline { 2 - 5 } & 1 & 1 & 2 & 3 \\
\hline \multirow{2}{*}{ Kekerapan } & 2 & 2 & 4 & 6 \\
\cline { 2 - 5 } & 3 & 3 & 6 & 9 \\
\hline Keterangan: & \multicolumn{4}{|c|}{ Skala Prioritas Rendah } \\
& $:$ & $\begin{array}{c}\text { Skala Prioritas Sedang } \\
\text { Skala Prioritas Tinggi }\end{array}$ \\
\end{tabular}




\section{HASIL DAN PEMBAHASAN}

Pekerjaan yang didentifikasi bahaya pada proyek Hotel Swiss-Belinn Juanda adalah pekerjaan kolom, balok dan plat, khususnya pekerjaan persiapan yang berupa pembersihan area, pengukuran awal, lalu pekerjaan pembesian, bekisting, pengecoran dan curing[9]. Dari pekerjaan-pekerjaan tersebut diidentifikasi potensi-potensi bahaya yang dapat terjadi dan potensi-potensi bahaya tersebut dinilai risikonya dengan matriks skala prioritas.

Tabel 4. Identifikasi dan Penilaian Risiko
\begin{tabular}{|l|c|c|c|}
\hline \multirow{2}{*}{$\begin{array}{l}\text { IDENTIFIKASI } \\
\text { BAHAYA }\end{array}$} & \multicolumn{3}{|c|}{ PENILAIAN RISIKO } \\
\cline { 2 - 4 } & $\begin{array}{c}\text { KEKERAP } \\
\text {-AN }\end{array}$ & $\begin{array}{c}\text { KEPARAH } \\
\text {-AN }\end{array}$ & $\begin{array}{c}\text { TINGKAT } \\
\text { RISIKO }\end{array}$ \\
\hline $\begin{array}{l}\text { A. Pekerja } \\
\text { kejatuhan } \\
\text { alat/material }\end{array}$ & $\begin{array}{c}1 \\
\text { (Jarang) }\end{array}$ & 3 (Berat) & $\begin{array}{c}3 \\
\text { (Sedang) }\end{array}$ \\
\hline $\begin{array}{l}\text { B. Pekerja } \\
\text { cedera akan } \\
\text { kontak } \\
\text { langsung } \\
\text { dengan alat } \\
\text { berat }\end{array}$ & $\begin{array}{c}1 \\
\text { (Jarang) }\end{array}$ & 3 (Berat) & $\begin{array}{c}3 \\
\text { (Sedang) }\end{array}$ \\
\hline $\begin{array}{l}\text { C. Pekerja } \\
\text { terkena debu }\end{array}$ & $\begin{array}{c}3 \\
\text { (Sering) }\end{array}$ & $\begin{array}{c}2 \\
\text { (Sedang) }\end{array}$ & $\begin{array}{c}6 \\
\text { (Tinggi) }\end{array}$ \\
\hline $\begin{array}{l}\text { D. Pekerja } \\
\text { terpeleset }\end{array}$ & $\begin{array}{c}2 \\
\text { (Sedang) }\end{array}$ & $\begin{array}{c}1 \\
\text { (Ringan) }\end{array}$ & $\begin{array}{c}2 \\
\text { (Sedang) }\end{array}$ \\
\hline $\begin{array}{l}\text { E. Pekerja } \\
\text { terkena } \\
\text { kontak listrik }\end{array}$ & $\begin{array}{l}\text { (Jarang) } \\
\text { F. Pekerja } \\
\text { terjatuh dari } \\
\text { ketinggian }\end{array}$ & $\begin{array}{l}3 \text { (Berat) } \\
\text { (Jarang) }\end{array}$ & $\begin{array}{c}3 \\
\text { (Sedang) }\end{array}$ \\
\hline
\end{tabular}

Dari identifikasi bahaya tersebut akan direncanakan pengendalian risiko[9], sebagai berikut :

1) Sosialisasi/Safety Talk/Tool Box Meeting;

2) Training;

3) Dipasang Rambu;

4) Penggunaan Safety Harness;

5) Pemasangan Safety Net;

6) Dipasang Hard Barricade;

7) Pemasangan Tangga Naik dan Jalur Evakuasi;

8) Disediakan APAR;

9) Asuransi dan Sertifikasi Pekerja;

10) Manajemen Kebersihan dan Kerapihan Lokasi;

Pengendalian risiko tersebut direncanakan untuk mengendalikan risiko potensi-potensi bahaya yang memiliki skala prioritas sedang dan tinggi. Untuk skala prioritas yang rendah, maka 
pengendalian risiko cukup dengan obat-obatan dan P3K, pelatihan terkait serta penggunaan alat pelindung diri (APD), (Republik Indonesia, 2016).

APD merupakan kewajiban pekerja untuk digunakan sehingga APD bukan merupakan suatu pengendalian risiko dari bahaya yang terjadi. Potensi bahaya yang tergolong dalam skala prioritas rendah adalah pekerja tersandung, pekerja terjepit alat, dan pekerja mengalami kebisingan. Yang masuk dalam kategori APD adalah helm, sepatu safety, kacamata pelindung, masker, dan rompi. Rincian biaya pengendalian K3 (republik Indonesia, 2015), mencakup:

1. Penyiapan RK3K;

2. Sosialisasi dan promosi K3;

3. Alat pelindung kerja[3];

4. Alat pelindung diri[4];

5. Asuransi dan perijinan[5];

6. Personil K3;

7. Fasilitas sarana kesehatan[6];

8. Rambu-rambu; dan

9. Lain-lain terkait pengendalian risiko K3[7].

\section{KESIMPULAN}

Berdasarkan hasil identifikasi bahaya menggunakan metode Job Safety Analysis, potensi bahaya yang ada dan dikendalikan di proyek tersebut antara lain kejatuhan alat/material, pekerja cedera akan kontak langsung dengan alat, pekerja terkena debu, pekerja terpeleset, hingga pekerja terkena kontak listrik. Dari perencanaan SMK3 tersebut didapatkan biaya pengendalian K3 sejumlah Rp 310.266.500,00 yang digunakan untuk pengendalian bahaya yaitu pelatihan K3, kelengkapan Safety Harness, rambu-rambu, hingga P3K dan APAR.

\section{DAFTAR PUSTAKA}

Ilo. (1995). Safety, Health and Welfare on Construction Sites: A Training Manual. Geneva.

Indonesia, R. (1980). Peraturan Menteri Tenaga Kerja dan Transmigrasi No.04/MEN/1980 tentang

Syarat-Syarat Pemasangan dan Pemeliharaan Alat Pemadam Api Ringan. Jakarta.

republik Indonesia. (2015). Surat Edaran No.66/SE/2015 tentang Biaya Penyelenggaraan Sistem

Manajemen Keselamatan dan Kesehatan Kerja (SMK3) Konstruksi Bidang Pekerjaan Umum. Jakarta.

Republik Indonesia. (2016). Peraturan Menteri Ketenagakerjaan No.09 Tahun 2016 tentang Kesehatan

dan Keselamatan Kerja dalam Pekerjaan pada Ketinggian. Jakarta.

International Labour Organization (ILO). 2013. Keselamatan dan Kesehatan Kerja. Jakarta.

International Labour Organization (ILO). 1995. Safety, Health and Welfare on Construction Sites: A Training Manual. Geneva.

Ramli, Soehatman. 2013. SMART SAFETY Panduan Penerapan SMK3 yang Efektif. Jakarta: Dian Rakyat.

Republik Indonesia. 2014. Peraturan Menteri Pekerjaan Umum No.05/PRT/M/2014 tentang Pedoman Sistem Manajemen Keselamatan dan Kesehatan Kerja (SMK3) Konstruksi Bidang Pekerjaan Umum. Jakarta.

Republik Indonesia. 2015. Surat Edaran No.66/SE/2015 tentang Biaya Penyelenggaraan Sistem Manajemen Keselamatan dan Kesehatan Kerja (SMK3) Konstruksi Bidang Pekerjaan Umum. Jakarta. 